\title{
SINO/AMERICAN COOPERATION FOR PV DEVELOPMENT IN THE PEOPLE'S REPUBLIC OF CHINA
}

\author{
William L. Wallace and Y. Simon Tsuo \\ National Renewable Energy Laboratory, 1617 Cole Blvd., Golden, Colorado 80401, USA
}

\begin{abstract}
Rapid growth in economic development, coupled with the absence of an electric grid in large areas of the rural countryside, have created a need for new energy sources both in urban centers and rural areas in China. Environmental pollution from the increased use of coal-fired steam turbines to meet this capacity expansion is a concern. There is a growing interest in China to develop renewable-energy resources and technologies to meet energy demands and help mitigate pollution problems. In February 1995, Secretary Hazel O'Leary of the U.S. Department of Energy signed an Energy Efficiency and Renewable Energy Protocol Agreement with the Chinese State Science and Technology Commission in Beijing, China. Under this agreement, projects using photovoltaics for rural electrification are being conducted in Gansu Province in western China and Inner Mongolia in northern China, providing the basis for much wider deployment and use of photovoltaics for meeting the growing rural energy demands of China.
\end{abstract}

\section{BACKGROUND}

Recently, the Ministry of Electric Power in China announced that China must install 100 to 130 gigawatts of new electric generating capacity by the year 2000 to meet the demands of the rapidly growing economy and to provide electricity to a large number of rural people presently without access to the electric grid [1]. Environmental pollution from the increased use of coal-fired steam turbines to meet this capacity expansion is a serious concern. As a consequence of these factors, there is growing interest in China to develop renewable-energy resources and technologies to meet energy demands and help mitigate pollution problems. Interest in renewable energy is reflected both at the central government level in Beijing and at the local level in the provinces and autonomous regions of China.

China has an abundance of renewable-energy resources in the form of solar, wind, biomass, hydro, geothermal, and ocean tidal resources. China is also already one of the world's largest users of renewables, primarily in the form of hydropower and biomass [2]. The solar resource of the countiy is also enormous and is strategically located in areas of greatest need in terms of rural energy development. More than 120 million rural people in northern and western China and more than 300 coastal islands currently have no access to the electric power grid and no near-term prospects for grid connection. There is an excellent match of solar and wind resources to meet these rural electrification needs. For example, the richest solar-energy resources in China are located in Inner Mongolia, Qinghai-Tibet Plateau, Northern Ningxia and Gansu Provinces. These are regions where population density is low, and it is often too costly or impractical for grid extension to reach many of the potential users.

In the central government of the People's Republic of China, three commissions under the State Council are actively involved in renewable energy: the State Planning Commission (SPC), the State Economic and Trade Commission (SETC), and the State Science and Technology Commission (SSTC). The SPC is in charge of planning and budget approval for large infrastructure projects. The SETC is in charge of industrialization and retrofitting existing industries. The SSTC is in charge of planning and program administration of scientific research and development projects. Project implementation and management are the responsibilities of various ministries, such as the Ministry of Electric Power (MEP) and the Ministry of Agriculture (MOA). In February 1995, Hazel O'Leary, Secretary of the U.S. Department of Energy (DOE), signed the Energy Efficiency and Renewable Energy Protocol Agreement with the SSTC in Beijing that established a broad umbrella for Sino/American cooperation to develop renewable-energy technologies and markets in China.

Prior to and since the signing of the protocol agreement, DOE has been working closely with key renewable-energy departments in the SPC, SSTC, and SETC, in providing assistance and support for China's renewable-energy planning activities. Such activities include preparing the Agenda 21, "White Paper on China's Population, Environment, and Development in the 21st Century," and encouraging renewable-energy project development for China's Ninth Five-Year Plan, for the period of 1996 to 2000 . Under the framework for cooperation established by the protocol agreement, DOE is developing three project annexes: (1) with MOA, for rural energy development, (2) with MEP and other key organizations, for wind energy and hybrid system cooperation, and (3) with SETC, for business development activities. National Renewable Energy Laboratory (NREL) is assisting DOE in implementing projects under the protocol agreement in China. 


\section{PHOTOVOLTAIC DEVELOPMENT IN CHINA}

The People's Republic of China has a long history of research and development of photovoltaic (PV) solar cells. PV solar-cell research for space applications began in China in 1958. The first space PV power system for a Chinese satellite (SJ-1) was deployed in 1971. There are now two organizations that specialize in manufacturing space PV power systems: Tianjin Institute of Power Sources and Shanghai Xin Yu Power Supply Factory. Terrestrial applications of PV in China began more than 20 years ago, in 1974, when China installed a PV-powered, navigation beacon light system in the Bohai Ocean. Commercial production of terrestrial solar cells began in 1976. The current installed capacity of PV systems in China is small, but is growing rapidly. In 1993, the installed capacity of PV systems was about $3.8 \mathrm{MW}_{\mathrm{p}}$; in 1994, the installed capacity was about $5.1 \mathrm{MW}_{\mathrm{p}}$; and in 1995, the installed capacity was about $6.3 \mathrm{MW}_{\mathrm{p}}[3]$. Some $60 \%$ of this capacity is power for telecommunications applications.

About $1.5 \mathrm{MW}_{p}$ of the PV generating capacity is installed in remote, agricultural, and village power applications, for which opportunities exist throughout China. There are more than 10,000 rural household systems already installed, mostly in Inner Mongolia, Tibet, and Qinghai. Household systems generally range from 20 to 80 $W$ and are used for lighting and small consumer electronics. The potential is excellent for increased use of PV solar home systems in China's northwest provinces. For example, according to the Qinghai Provincial Electric Power Bureau, there are 107,000 unelectrified households in the province, and the Bureau plans to subsidize the electrification of 15,000 households using PV solar home systems by the year 2000. There are six $7-$ to $25-\mathrm{kW}$, stand-alone PV power stations in China, five in Tibet, and one in Gansu. A $30-\mathrm{kW}$, stand-alone power station is under construction in Tibet. China also has experience with wind/PV hybrid systems in the range of $200 \mathrm{~W}$ to $35 \mathrm{~kW}$, but at present China has no experience with grid-connected PV systems. However, the quality of grid-connected electricity is a pervasive problem, and the use of PV for grid-support, uninterruptible power supplies and peak-shaving applications in the potential urban market is of great interest.

At least 16 organizations in China have manufactured and sold crystalline or amorphous silicon PV modules for terrestrial applications, with a total manufacturing capacity of about 5.5 $\mathrm{MW}_{\mathrm{p}}$. However, many of them have either stopped production or are not manufacturing at full capacity because of a combination of the following: (1) outdated equipment (All of China's PV cell and module production lines were imported before 1991.), (2) high manufacturing costs due to lack of automation and small-scale production, and (3) shortage of silicon wafers. Presently, only five organizations in China have an annual production level of PV modules of more than $200 \mathrm{~kW}$ : Qinhuangdao Huamei Photovoltaics Electronics, Corp. Ltd.; Yunnan Semiconductor Device Factory; Kaifeng Solar Cell Factory; Ningbo Solar Power Supply Factory; and Harbin-Chronar
Solar Energy Electricity Corp. Chinese-made modules have a significant price advantage over American-made modules when the module size is less than $50 \mathrm{~W}_{\mathrm{p}}$ because of lower labor costs and the $30 \%$ import tariff and value-added tax. When the module size is $50 W_{p}$ or greater, U.S. manufactured modules have a price advantage. Presently, Chinese module production cannot keep up with demand, and the average sales price has steadily increased during the last 2 years.

\section{RURAL ELECTRIFICATION IN WESTERN CHINA}

The high cost, lack of a marketing and distribution infrastructure, and variable quality of modules and balanceof-system components are barriers to the widespread deployment of photovoltaics in China. Several cooperative projects are being conducted in China to address these problems. Under the protocol agreement, NREL is working with the MOA and the State Council Office for Poverty Alleviation and Rural Development in Beijing to develop a cost-shared program to provide household PV electricity systems to rural families in Western China. This project is being conducted with the Solar Electric Light Fund (SELF), a non-profit organization in Washington D.C. This DOEfunded project is designed to expand and strengthen the distribution and postsales support infrastructure previously established in the Gansu province in China. This infrastructure involves a partnership between rural energy offices at the county and township level (under the MOA), provincial government agencies associated with the Poverty Alleviation program, and local PV system integrators in China. Rural energy offices exist at the township, district, and county level in all the provinces of China, and they can help facilitate rural electrification projects throughout China, providing a widespread infrastructure for technology deployment. The use of revolving funds for credit and cash sales for financing the purchase of household systems to expand the market for $\mathrm{PV}$ is a critical component of the project.

Fifty percent of the cost of the project is provided by the Chinese government through the Gansu Provincial Poverty Alleviation and Rural Development Office, Gansu Planning Commission, and Gansu Economic and Trade Commission. The China side of the project is managed by the Gansu Solar Electric Light Fund (GSELF), which was established in 1993 for the specific purpose of promoting solar home systems in Western China. In MaGiacha village in Tonwei County, Gansu Province, GSELF installed 112 solar home systems of $20 \mathrm{~W}$ each in 1993 , with partial financial support from the Rockefeller Foundation through SELF. In the MaGiacha project, each householder provided a 300 Yuan down payment and agreed to pay 12 Yuan/month for 12 years, which totals $80 \%$ of the cost with no interest charge. Additionally, GSELF is installing 172 solar home systems financed by the United Nations Development Program. The current DOE project is based primarily on cash sales, with a $80 \%$ overall cost recovery for the project based on an average selling price for local vendors of solar home systems. A revolving-fund account 
will be set up at the Lanzhou Branch of the China Construction Bank for purchasing additional systems. During the project cycle of 18 months (April 30, 1996 to October 31, 1997), PV solar home systems will be expanded from 400 sets at the start to at least 600 sets by project's end (based on nominal 20-watt systems).

PV panels and sealed lead-acid batteries will be purchased from the United States and other balance-ofsystem components (including charge controllers, compact fluorescent lights, and wiring) will be provided by three loca system integrators: the Gansu PV Company, the Gansu Z Neng Automation Engineering Company, and the Zhong Xing Electronic Instruments Factory. The training of rural technicians and management staff of local service networks is included in the project. A "train the trainers" training session will be conducted jointly by U.S. and China technical experts. From this base, the project will strengthen and expand the sales and service infrastructure in Gansu, and will gradually expand to build service networks for PV solar home systems in the provinces, counties, townships, and villages in western China. At the same time, the project will increase market acceptance of American-made components.

\section{PV CASE STUDIES IN INNER MONGOLIA}

In collaboration with the Chinese Academy of Science (CAS) in Beijing and the Center for Energy and Environmental Policy (CEEP) at the University of Delaware in the United States, NREL is also working with several agencies of the Inner Mongolian government and several key investors in Inner Mongolia to develop PV and PV/wind hybrid projects in Inner Mongolia. The government of Inner Mongolia is committed to a village electrification program over the next 5 years, which will involve in the near term the electrification of 47 township centers by the end of 1997 using renewable-energy technologies. Inner Mongolia also has an established distribution infrastructure for rural energy system deployment at the county and village level that can provide an infrastructure for PV market development. This infrastructure has already been used to electrify approximately 110,000 households in rural Inner Mongolia using wind turbines in the $100 \mathrm{~W}$ to $300 \mathrm{~W}$ size range. By the end of 2000, approximately 80,000 more households are targeted for electrification using a combination of wind and PV systems. Involvement of the local electricity bureau is a key component of this project. Local electricity bureaus, at the provincial and county levels, potentially represent a national infrastructure for technology deployment throughout China.

A series of case studies is being conducted by CAS, CEEP, and NREL for household and village power systems in Inner Mongolia, to develop technical and economic performance data and information. A report, "Levelized Cost Analyses of Small-Scale, Off-Grid Photovoltaic, Wind and PV-Wind Hybrid Systems for Inner Mongolia, China," was recently published [4]. This report summarizes levelized cost analyses performed on 41 household-scale PV $(22 \mathrm{~W}$ to $1 \mathrm{~kW})$, wind (100 W to $2 \mathrm{~kW}$ ), and $P V$-wind hybrid systems operating in four counties in Inner Mongolia. The report concludes that from a systems and users perspective, levelized costs of renewable-energy home and village power systems are lower than using gasoline or diesel generators. While wind energy tends to be the lowest cost option for rural applications, the seasonal variability of wind and solar resources makes hybrid wind/PV systems with battery storage for household and village power systems, an attractive option in areas where there is a seasonal complementarity between solar and wind resources. This seasonal complementarity between wind and solar resources may be important in other provinces in China as well. In Inner Mongolia, there are at present, 300,000 households without electricity.

\section{ACKNOWLEDGEMENT}

The authors wish to thank Neville Williams and Robert Freling at the Solar Electric Light Fund in Washington, D.C., John Byrne and Bo Shen at the Center for Energy and Environmental Policy at the University of Delaware, Li Xiuguo at the Chinese Academy of Sciences in Beijing, and Wang Si Cheng at the Energy Research Institute in Beijing for technical assistance related to this paper.

This work was supported by the U.S. Department of Energy under contract number DE-AC36-83CH10093 to the National Renewable Energy Laboratory.

\section{REFERENCES}

[1] Y. Lian, Renewable Energy Programs and Projects in China, published in 1994 by the Division of Renewable Energy Power, Ministry of Electric Power, The People's Republic of China.

[2] See, for example, Solar Energy in China, Yan Luguang and Kong Li, editors, Chinese Academy of Sciences, Beijing, China; 1995.

[3] Wang Sicheng, Energy Research Institute of the State Planning Commission, "Current Status of PV in China and Typical PV System Analysis," 1996, unpublished.

[4] John Byrne, et. al., "Levelized Cost Analyses of SmallScale, Off-Grid Photovoltaic, Wind, and PV-Wind Hybrid Systems for Inner Mongolia, China," March 1996, Center for Energy and Environmental Policy, University of Delaware, Newark, Delaware. 